\title{
Strengthening the National Human Rights Commission of Bangladesh through a Legislative Amendment to Fulfill its Commitments Under Sustainable Development Goals (SDGs)
}

\author{
A B M Asrafuzzaman"
}

\section{Introduction}

As a member of the UN, Bangladesh is under international obligations to promote, protect, and enforce human rights and human development under a variety of international Conventions and instruments, including the International Covenant on Civil and Political Rights 1966 ( ICCPR), the International Covenant on Economic Social and Cultural Rights 1966 (ICESCR), the Convention on the Elimination of All Forms of Discrimination Against Women (CEDAW), the Paris Declaration, and the Sustainable Development Goals (SDGs).To fulfill those commitments, the National Human Rights Commission of Bangladesh (Commission or NHRC) could have played a significant role in safeguarding human rights. Because of some inherent lacunae in the National Human Rights Commission Act 2009 (NHRC Act), the Commission has, to a substantial extent, failed to promote, protect, and enforce human rights and human development in Bangladesh. These lacunae include: (1) an incomplete definition of "human rights"; (2) a defective appointment procedure and very minimal qualifications for the appointment of Chairman and commissioners, and the insufficient number of permanent members of the Commission; (3) a lack of enforcement mechanism in the hands of the NHRC and inability to provide interim relief to aggrieved complainants; (4) it has only investigative power and its recommendations to the government are non-binding; (5) the Commission's lack of independence from the government; (6) the exclusion of some significant issues from its jurisdiction. To strengthen the Commission's power of promotion, protection, and enforcement of human rights, the government must significantly amend the NHRC Act to address these lacunae and to fulfill its international commitments.

This paper will first provide an overview of Bangladesh's human rights commitments under international law. Part II will discuss the historical background, composition, power, and functions of NHRC. Part III will depict human rights conditions in Bangladesh. Part IV will delve into the judicial approach towards the actions of the NHRC. Part V will identify the flaws and lacunae in the NHRC Act. Part VI will scrutinize key provisions of the NHRC Act and compare them to the enabling provisions of the human rights bodies of India, Nepal, and South Africa. Finally, Part VII will

\footnotetext{
* Lecturer, Department of Law, University of Dhaka, Bangladesh.
} 
recommend amendments to the NHRC Act based on those flaws and comparisons. This paper will explore the likely results of amendments to the NHRC Act based on logical inference (less on empirical observation). The author acknowledges that full implementation of the NHRC Act, even if amended, will be challenging.

\section{Bangladesh's Human Rights Commitments and the NHRC}

\subsection{Definition of Human Rights}

"Human rights" has been defined by the international human rights documents, the NHRC Act, and human rights scholars. The word "human" implies human beings and "rights" signifies entitlement. Thus, whenever and wherever a human being is born, he/she will be entitled to certain basic rights from the very day of his/her birth. These fundamental rights can be termed as natural rights. These rights are not conditioned on nationality, race, religion, sex, or other immutable traits. The philosophy is that the concept of human rights does not entail recognition or ratification by the State because they are natural rights of human beings.

The NHRC Act defines "Human Rights" as Right to life, Right to liberty, Right to equality and Right to dignity of a person guaranteed by the Constitution of the People's Republic of Bangladesh and such other human rights that are declared under different international human rights instruments ratified by the People's Republic of Bangladesh and are enforceable by the existing laws of Bangladesh. ${ }^{1}$ This definition does not cover all traits of human rights. It encompasses only the human rights which have been recognized by the Constitution of Bangladesh, enforceable by law, and contained in different international instruments ratified by Bangladesh. The plain language of the definition expressly concentrates more on civil and political rights than the social, economic and cultural rights of the citizens.

\subsection{International Commitments Behind the Formation of the NHRC}

\subsubsection{Key Human Rights Instruments Adopted by Bangladesh}

Bangladesh has commitments to protect, promote, and enforce human rights and human development under the Charter of United Nations, ICCPR, ICESCR, CEDAW, Universal Declaration of Human Rights (UDHR), Convention on the Rights of the Child 1989 (CRC), Convention on the Elimination of All Forms of Racial Discrimination 1965 (CERD), Convention Against Torture and Other Cruel, Inhuman or Degrading Treatment or Punishment 1984 (CAT), Convention on the Rights of Person with Disabilities, 2006 (CRPD), SDGs, Paris Declaration, and Vienna Declaration.

National Human Rights Commission Act 2009 (Bangladesh) (hereinafter NHRC Act 2009), s 2(f) <https://nhrc.portal.gov.bd/sites/default/files/files/nhrc.portal.gov.bd/law/de62d323_fe91_45f0_9513 _a0d36ab77fdf/NHRC\%20Act\%202009_1_.pdf> accessed 12 July 2020. 
The underlying purpose of the UN Charter is to impose an obligation on its members to take initiatives to respect and recognize human rights and the fundamental freedom of people without any distinction as to race, sex, religion, ethnicity, or language. ${ }^{2}$ One of the core goals of it is to ensure peace within and among States. It is implausible to achieve this goal without the proper implementation of human rights. Consequently, the UN charter, in its starting provisions, has contained articles urging member States to respect human rights and fundamental freedoms.

The ICCPR casts obligations upon the State Party to undertake proper measures to respect civil and political rights, such as freedom of expression, recognized in the Covenant to all individuals within its territory and subject to its jurisdiction, without distinction of any kind, such as race, color, sex, language, religion, political or other opinions, national or social origin, property, birth or other status. ${ }^{3}$ Consequently, every member State is obliged to fulfill all civil and political rights of the people guaranteed under this Convention. It also requires that when fundamental freedom of any person will be violated, he/she will have an adequate remedy under the law, and the State shall guarantee that the competent authorities shall enforce such remedies when granted. ${ }^{4}$ It imposes a duty upon the State to ensure the equal right of people to the enjoyment of all civil and political rights outlined in this covenant. ${ }^{5}$ Thus, it casts an obligatory duty upon the State not only to take proper measures to enforce the rights enshrined in it but also to enforce remedy when granted to the victim. It also urges the State to endorse the principle of equality between men and women in enjoying their civil and political rights and prohibits gender discrimination.

The ICESCR sets forth economic, social, cultural rights and requires each State Party to undertake to respect and to ensure to all individuals within its territory and subject to its jurisdiction the rights recognized in the covenant, without distinction of any kind, such as race, color, sex, language, religion, political or other opinion, national or social origin, property, birth or other status. ${ }^{6}$ It stipulates that the States Parties to this Covenant shall undertake to guarantee that the rights enunciated in the Covenant will be exercised without any kind of discrimination. ${ }^{7}$ It also requires that the States Parties to this Covenant shall undertake to make sure the equal right of people to the enjoyment of all economic, social, and cultural rights outlined in this covenant. ${ }^{8}$ Thus, every State Party is obliged to take adequate measures to guarantee

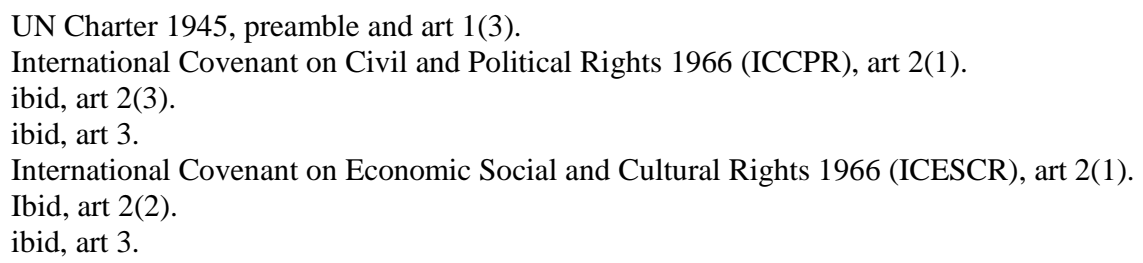


economic, social, and cultural rights mentioned in it without any kind of distinction. It also urges the State Party to make sure equality between men and women in the realization of these rights.

The CEDAW talks about the equal rights of men and women. It requires the State to take all measures to eliminate all kinds of discrimination against women and safeguards to protect the rights of women. However, Bangladesh has reservations to Article 2 and 16(1)(c), which deal with the State's obligation to take steps to wipe out all kinds of discrimination against women and to safeguard equal rights of women concerning the family law issues. By this reservation, Bangladesh has skipped core obligations under this Convention. It is pertinent to mention here that the Constitution of Bangladesh has guaranteed the equal rights of both men and women in all spheres of the State. ${ }^{9}$ Despite this kind of reservation, Bangladesh has the fundamental constitutional mandate to eliminate all kinds of discrimination irrespective of gender in state and public life.

The CRC stipulates that States Parties shall respect and safeguard the rights outlined in this Convention to each child within their jurisdiction without discrimination of any kind, irrespective of the child's or his/her parent's or legal guardian's race, color, sex, language, religion, political or other opinion, national, ethnic or social origin, property, disability, birth or other status. ${ }^{10}$ It requires that no child shall be subjected to arbitrary or unlawful intrusion with his or her privacy, family, home or correspondence, or unlawful attacks on his/her honor and reputation. ${ }^{11}$ The child has the right to the protection of the law against such interference or attacks. ${ }^{12}$ It also requires that States Parties shall undertake to protect the child from all forms of sexual exploitation and sexual abuse. ${ }^{13}$ It provides that States Parties shall make sure that no child shall be subjected to torture or other cruel, inhuman, or degrading treatment or punishment. ${ }^{14}$ The combined effect of the provisions of the CRC requires that every State Party shall care for the rights of the children within its territory. Thus, every State will take all legal safeguards to protect the rights of the children. They are also duty-bound to provide the effective and appropriate remedy to children who become the victim of unlawful torture and intrusion. Bangladesh has reservations to article 14(1) and 21of this Convention. Article 14(1) requires that States Parties shall respect the right of the child to freedom of thought, conscience, and religion. It takes reservations on the ground that in

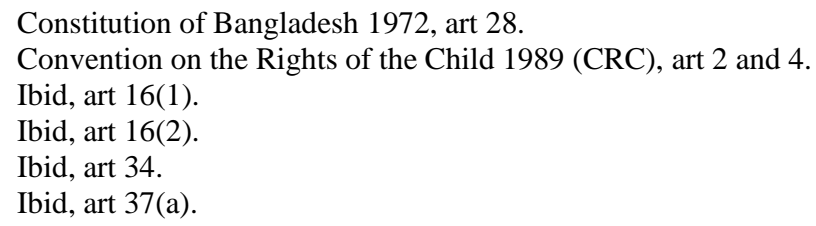


Bangladesh, most people believe in Islam, and renunciation of Islam is a great $\sin ^{15}$ However, it is contrary to the Constitution of Bangladesh, which recognizes secularism as one of its four fundamental principles. Hence, Bangladesh cannot maintain any specific tenet of religion. Despite this reservation, Bangladesh has a constitutional obligation to abide by the secular principle in administering its activities.

The CAT requires that each State Party shall take effective legislative, administrative, judicial, or other measures to prevent acts of torture in any territory under its jurisdiction. ${ }^{16}$ It states that each State Party shall ensure that any individual who alleges that he has been subjected to torture in any territory under its jurisdiction has the right to complain to and to have his case promptly and impartially examined by its competent authorities. ${ }^{17}$ It also requires that steps shall be taken to ensure that the complainant and witnesses are protected against all ill-treatment or intimidation because of his complaint or any evidence given. ${ }^{18}$ It also stipulates that each State Party shall undertake to prevent in any territory under its jurisdiction other acts of cruel, inhuman or degrading treatment or punishment which do not amount to torture as defined in Article I, when such acts are committed by or at the instigation of or with the consent or acquiescence of a public official or other person acting in an official capacity. ${ }^{19}$ Thus, under the CAT, each State Party must take all appropriate steps to protect its people from the cruel, inhuman and degrading treatment or punishment and at the same time, the State shall take proper measures to afford a quick and effective remedy to the person who is the victim of unlawful torture.

The Sustainable Development Goals (SDGs) are the blueprint to build a better and more sustainable future for all people around the world. They focus on the global challenges including poverty, quality health, quality education, gender inequality, climate change, environmental degradation, sustainable energy, economic development, peace, and justice. All the contracting parties have pledged to fulfill these goals by taking robust action within their respective countries by 2030 . It requires that independent, accountable, pro people, and inclusive institutions are necessary to fulfill these goals. Goal five of the SDGs requires that every State Party shall take proper steps to achieve gender equality and empower all women and girls.

15 'Reservations to the Convention on the Rights of the Child: A Look at the Reservations of Asian State Parties' (International Commission of Jurists, 1 February 1994) <https://www.icj.org/ wpcontent/uploads/2013/10/Asia-Convention-Rights-of-the-Child-non-legal-submission-1994eng.pdf> accessed 20 March 2020.

16 Convention against Torture and Other Cruel, Inhuman or Degrading Treatment or Punishment 1984 (CAT), art 2(1).

17 ibid, art 13.

18 ibid.

19 ibid, art 16. 
Goal ten entails that every State Party shall take appropriate measures to reduce inequality within and amongst States. Goal 16 requires that every State shall promote peaceful and inclusive societies for sustainable development, provide access to justice for all and build effective, accountable, and inclusive institutions at all levels. The core spirit of the SDGs is to ensure human rights for all. It advocates that without the realization of human rights, it is implausible to ensure sustainable development. After all, it urges that without founding an effective, accountable, and inclusive institution, it may be implausible to enforce, protect, and promote human rights and human development.

\subsubsection{The Paris Principles and the Formation of National Human Rights bodies}

The obligations outlined in the instruments described above form the foundation for establishing national human rights institutions like Bangladesh's NHRC for the protection, promotion, and enforcement of human rights and human development. Because of repeated violations of human rights by States worldwide, the representatives of most States met in Paris to think about how to make up the human rights Conventions more effective in the lives of citizens. Consequently, representatives of States developed the Paris Principles, which urge every member State to set up a national human rights institution to protect, promote, monitor, and fulfill the human rights of the people. The UN Commission on Human Rights and the UN General Assembly approved these principles subsequently. ${ }^{20}$ Thus, it became the obligation of all member States to establish national human rights institutions for the protection and promotion of human rights and human development.

The World Conference on Human Rights reiterates the importance and constructive role played by national human rights institutions for the promotion and protection of human rights, in particular in their advisory capacity to the competent authorities, their role in remedying human rights violations, in the dissemination of human rights information, and education in human rights. ${ }^{21}$ This Conference encourages the establishment and strengthening of national institutions, having regard to the "Principles relating to the status of national institutions" and recognizing that it is the right of each State to choose the framework which is best suited to its particular needs at the national level. ${ }^{22}$ To comply with obligations under the above mentioned international legal instruments, the Parliament of Bangladesh has enacted the NHRC Act to found NHRC in order to promote, protect, and monitor the human rights of the people of Bangladesh.

\footnotetext{
${ }^{20}$ General Assembly Resolution 48/134 of 20 December 1993.

${ }^{21}$ Vienna Declaration and Program of Action 1993, art I (36).

22 ibid.
} 


\section{The NHRC of Bangladesh}

\subsection{The Historical milieu of the formation of the NHRC}

In the 1990s, the civil society and international community raised their voices demanding the setting up an independent and neutral State institution to ensure the accountability of the State. ${ }^{23}$ It was anticipated that this institution would offer the State with the necessary guidelines and recommendations for guaranteeing human rights. This institution was also expected to pave the way for the protection of human rights defenders. Consequently, in 1996, the government took a strategy to gauge the prospect of forming the NHRC. ${ }^{24}$ Afterward, with the assistance of UNDP, a draft Act was proposed in 1998 to form the Commission. However, the legacy of negligence and ineptitude of the previous regime was still prevalent. Thus, the issue was untouched and under consideration for a prolonged period. At last, a Commission was established on the 1st September of 2008 with the promulgation of the National Human Rights Commission Ordinance 2007, by the caretaker government (an interim non-elected government). A three-member Commission began functioning on 1st December 2008. ${ }^{25}$ However, the NHRC takes the present shape and comes into people's discussion after the enactment of the NHRC Act 2009, on 14th July 2009. The NHRC started functioning in June 2010 under this Act. The second Commission worked for two terms consecutively until June 2016. Then the fourth Commission commenced its journey on the 2nd August of 2016. The present one is the fifth Commission, which has taken charge on the 22nd September of $2019 .{ }^{26}$ The Chairman of the first Commission was a former Justice of the Supreme Court of Bangladesh; the second \& third Commission was a professor of law; the fourth was a former bureaucrat, and the fifth Commission is also a retired bureaucrat.

\subsection{Composition of the NHRC}

Under the NHRC Act, the Commission shall consist of a Chairman and not more than six members. The Chairman and one member of the Commission shall be full time, and other members shall be honorary. Among the members, at least one shall be a woman, and one shall be from an ethnic group. The Chairman shall be the chief executive of the Commission. ${ }^{27}$ The President shall, upon the recommendation of the selection committee, appoint the Chairman and the members of the Commission. ${ }^{28}$ To

23 Ain O Salish Kendra, Report on Civil Society Dialogue with National Human Rights Commission Bangladesh <http://www.askbd.org/ask/2017/12/10/report-civil-society-dialogue-nhrc/> accessed 20 March 2020.

ibid.

ibid.

National Rights Commission Bangladesh, Annual Report (NHRC 2018) 13 <http://nhrc.portal. gov.bd/sites/default/files/files/nhrc.portal.gov.bd/page/cb8edec9_5aee_4b04_bf2a_229d9cd226a0/

Annual\%20Report-2018\%20English.pdf > accessed 25 March 2020.

NHRC Act 2009 (Bangladesh), s 5.

ibid, s 6(1). 
make a recommendation on the appointment of the Chairman and members, a selection committee shall consist of the following seven members, namely:- (a) the Speaker of the House of the Nation who shall also be its President; (b) Minister, Ministry of law, Justice, and Parliamentary affairs; (c) Minister, Ministry of Home Affairs; (d) Chairman, Law Commission; (e) Cabinet Secretary, Cabinet Division; (f) Two Members of the Parliament, nominated by the Speaker of the House of the nation, out of whom one shall belong to the ruling party and the other from the opposition party. ${ }^{29}$ To make a recommendation on the appointment of the Chairman and the members, the selection committee shall recommend two names against each vacant post based on the decision of the majority of the votes of the members present in the meeting. In case of equality of votes, the persons presiding over the meeting shall have the right to exercise a casting vote. ${ }^{30}$

No person shall be eligible for appointment to the post of the Chairman or member of the Commission or shall hold a post if he is below 30 and over 70 years of age. The Chairman and the members shall, subject to the provision of this section, be appointed from amongst the persons who have remarkable contributions in the field of legal or judicial activities, human rights, education, social service, or human welfare. ${ }^{31}$

Thus, the Commission has only two permanent members, including its Chairman; and all other members are honorary. Honorary members do not actively take part in the functions of the NHRC. They only join in the meetings of the NHRC. It may be challenging for only two members to run all the functions of the NHRC efficiently around the entire country.

The President appoints the Chairman and members based on the recommendation of the selection committee, but the majority of the members of the selection committee belong to the ruling party and only one member from the opposition party. Hence, the government has scope to nominate those persons who will work on behalf of it and are likely to turn a blind eye to the government's role in human rights abuses.

\subsection{Functions of the NHRC}

The NHRC, a statutory body, has been founded to protect, enforce, and promote human rights in Bangladesh. Under the NHRC Act, it is obliged to undertake and implement diversified functions for the promotion and protection of human rights. As per section 12 (1) of the NHRC Act, it shall execute all or any of the following functions, namely:

\footnotetext{
Ibid, $\mathrm{s} 7$.

ibid.

31 NHRC Act 2009 (Bangladesh), s 6.
} 
- investigate any complaint against human rights breaches either on the complaint or suo motu.

- visit any jail or correctional centers, and such other similar places and make recommendations to the government thereon for the development of those places and their conditions.

- conduct research on various international documents relating to human rights and provide the government with necessary recommendations to enforce them.

- scrutinize the proposals for new legislation for verifying their compliance with international human rights benchmarks and to make recommendations for amendment to the appropriate authority.

- inquire complaints related to the infringement or possibility of the breach of human rights and resolve the issue through mediation.

- provide legal support to the victim of violations of human rights.

- conduct research on the human rights situation of the country.

- create consciousness as to human rights through enormous publicity and publications.

- provide training for members of law enforcement agencies and other persons concerned regarding the protection of human rights.

- perform such other functions, as may be necessary for the promotion of human rights.

Any careful reading of the abovementioned provisions relating to the functions of the NHRC, will show that it has possibly been overburdened with a bundle of duties to promote, enforce, and protect human rights and human development in Bangladesh. However, the execution and implementation of these functions depends on the will of the government.

\section{Human Rights Conditions in Bangladesh}

The fundamental rights of people guaranteed under the Constitution of Bangladesh are more in their breach than their observance, let alone all human rights. The daily newspapers of Bangladesh report human rights violations every day. The human rights report of newspapers, NHRC, national and international NGOs, and international human rights organizations reveal a pattern of increasing violations of human rights in Bangladesh. Recently, Bangladesh has graduated from the least developed countries category to a developing country. Though a little bit of advancement of socio-economic human rights is evident from the human rights report of NHRC and NGOs, civil and political rights are flouted and abused awfully in Bangladesh. The following types of violations of human rights are widespread and increasing alarmingly. 


\subsection{Arbitrary Arrest and Detention}

Arbitrary detention is a frequent phenomenon in Bangladesh. The government agencies detain people without showing sufficient cause to protect the interests of the government. The law enforcement agencies (Police, Rapid Action Battalion and Detective Branch) also arrested at least 100 students, most of whom participated in the quota reform and road safety protest movements in $2019 .{ }^{32}$ The Special Powers Act,1974 allows law enforcement agencies to arrest and detain an individual without an order from a magistrate or a warrant when such an agency contemplates that individual may be involved in a prejudicial act, which is a threat to security, interest and public order of the State. They can also detain people without producing them before the court for a prolonged period under this Act. The law enforcement agency rationalizes most of the arbitrary arrest and detention under this Act.

\subsection{Extrajudicial Killing}

The number of extrajudicial killings is increasing gradually in Bangladesh. The year of 2017 has witnessed an anti-drug drive in which more than 300 people were killed for allegedly being connected with the drug/narcotics business. ${ }^{33}$ More than 388 people were killed by the security forces in alleged extrajudicial executions, 279 people were killed before the arrest, 97 people were killed after the arrest, and others were killed after torture or other means. ${ }^{34}$ According to ASK reports from newspapers and its own source, 437 persons have been victims of extrajudicial killing from January to October 2018. ${ }^{35}$ Human Rights Support Society (HRSS), a domestic human rights organization, reported that the security forces killed more than 400 individuals in crossfire incidents from January to September. ${ }^{36}$ These reports clearly shows that the government is curtailing the right of the accused to assure trial. The law enforcement agency is killing people in the name of cross fire arbitrarily and without giving them an opportunity of being heard or fair trial.

\subsection{Unlawful Torture and Inhuman Treatment}

Inhuman treatment and unlawful torture are frequently used to extract information from accused persons. In most cases, an accused is compelled to make involuntary extrajudicial confession due to such inhuman treatment or unlawful

32 Bureau of Democracy, Human Rights, and Labor, Country Reports on Human Rights Practices: Bangladesh (US Department of State 2019) <https://www.state.gov/reports/2019-country-reports-onhuman-rights-practices/bangladesh/> accessed 20 March 2020.

33 Ain O Salish Kendra (n 23) 18.

34 Amnesty International, 'Bangladesh 2019'<https://www.amnesty.org/en/countries/asia-and-thepacific/bangladesh/report-bangladesh/> accessed 20 March 2020.

35 Tamanna Hoq Riti in Maimuna Syed Ahmed (ed), National Human Rights Commission, Bangladesh: Existing Challenges and Expectations of Civil Society (Ain O Salish Kendra 2018) 23$24<$ https://www.askbd.org/ask/wp-content/uploads/2019/02/NHRC-Report_English.pdf> accessed 15 February 2020.

36 Bureau of Democracy, Human Rights, and Labor (n 32). 
torture. The security forces reportedly use threats, beatings, kneecappings, electric shocks, and sometimes commits rapes and other sexual abuses in extracting confessional statement from the accused. ${ }^{37}$

In August of 2019, the UN Committee Against Torture (CAT) expressed deep concerns over allegations of widespread use of torture, mistreatment and soliciting the payment of bribes by Bangladeshi law enforcement officials to extract confessions. The CAT report also condemned the lack of publicly accessible information on abuse cases and the failure to ensure accountability for law enforcement agencies, particularly the Rapid Action Battalion (RAB). ${ }^{38}$ Although inhuman treatment and unlawful torture violate fundamental rights and human rights, they are usually employed by law enforcement agencies to gather information as to the commission of offenses. The cardinal principle of human rights is that nobody shall be compelled to give evidence against himself. Therefore, inhuman treatment and torture to extract information is a grave violation of human rights.

\subsection{Forced Disappearance}

Many people including wealthy businesspeople, political opponents, as well as critics of the government are frequently disappeared in Bangladesh. In most instances, the law enforcement agencies are assumed to be involved in such incidents. According to media reports, some of disappearances occurred in 2018. Mention may be made to Shajol Chowdhury's abduction. Mr. Shajol, an owner of several businesses, including a shipbreaking venture in Chittagong, has returned home a week after being abducted. ${ }^{39}$ According to ASK reports from national dailies, a total of 34 persons were victims of abduction, disappearance, and went missing in 2018. Of them, 19 have been traced subsequently, most of whom are in prison in different cases. ${ }^{40}$ The HRSS affirmed that there were 58 enforced disappearances from January to September, and Odhikar asserted that there were 83 enforced disappearances from January to November of $2019 .{ }^{41}$ These reports reveal that enforced disappearance have become turned out to be a common incident in Bangladesh. The government did not take any appropriate steps to stop this kind of violation of human rights. The government did not even respond to a request from the UN Working Group on Enforced Disappearances to visit the country. ${ }^{42}$ The report also implies that the government has failed to prevent this kind of severe violation of human rights.

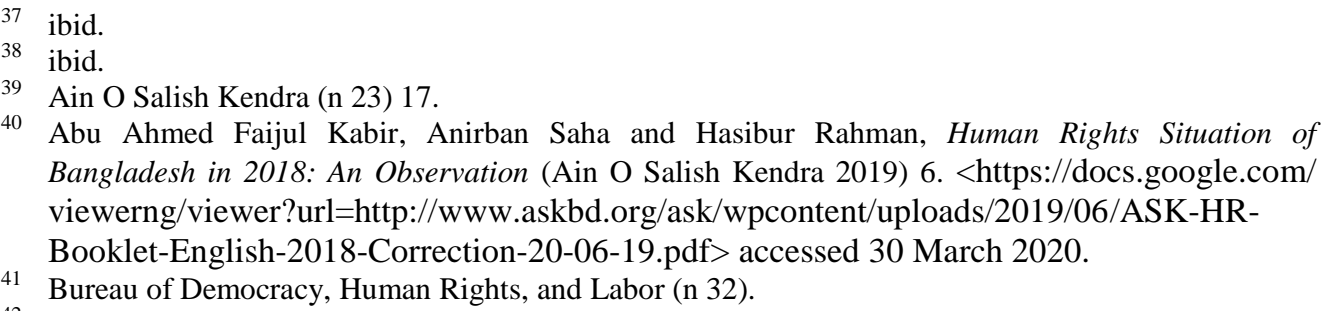




\subsection{Infringements of Rights of the Marginalized Communities}

Religious minority groups and ethnic communities are frequent victims of the attacks and violations of human rights in Bangladesh. In February 2018, two Marma girls in Rangamati were sexually assaulted by members of Ansar. In August 2018, 06 people were killed in Khagrachari by some miscreants. ${ }^{43}$ The NHRC urged the government to strengthen the law and order situation in Chittagong Hill Tracts areas to provide security to the ethnic minority people..$^{44}$ At least 43 indigenous political activists were killed and 67 injured mostly because of fighting between political factions. ${ }^{45}$ Police had not recorded first information report against Muslim villagers accused of vandalizing and burning approximately 30 Hindu houses in Rangpur in November 2017 in response to a rumored-on Facebook post demeaning Islam. ${ }^{46}$ These reports explore that religious minorities and ethnic communities are the vulnerable victims of violations of human rights in Bangladesh. Their human rights and fundamental freedoms are frequently flouted.

\subsection{Violations of Women's Rights}

Bangladesh's women are frequently victims of infringements of human rights and fundamental rights. Due to the lack of appropriate action and effective remedy, the number of violations in this arena is rising alarmingly. The report of the Global Alliance of National Human Rights Institutions (GANHRI) reveals that its members, including India, Nepal, and South Africa except Bangladesh, have taken the initiatives to prevent gender-based violence against women. ${ }^{47}$ The following kinds of violations of women's human rights are widespread in Bangladesh.

\subsubsection{Rape}

According to ASK documentation, a total of 732 women were victims of rape and gang-rape in the year 2018. Among them, 63 were murdered after rape, and 7 committed suicide. ${ }^{48}$

\subsubsection{Stalking and Sexual harassment}

In 2018, a total of 173 women and men became victims of sexual harassment and other kinds of violence; among them, 116 were women. As many as 8 women

43 Ain O Salish Kendra (n 23) 20.

44 ibid.

45 Amnesty International (n 34).

${ }^{46}$ Bureau of Democracy, Human Rights, and Labor (n 32).

47 Alexandre Bouchard and others,

Preventing and Eliminating All Forms of Violence against Women and Girls: The Role of National Human Rights Institutions - A Contribution to the Review and Priority Themes of CSW63 (GANHRI 2018) <https://nhri.ohchr.org/EN/Documents/DIMR_GANHRI\%20CSW\%20Report_final\%20BF.pdf> accessed 20 March 2020.

${ }^{48}$ Ain O Salish Kendra (n 40). 
committed suicide due to sexual harassment. Twelve persons, including 3 women, were murdered. ${ }^{49}$

\subsubsection{Dowry and Domestic Violence}

In 2018, a total of 195 women became victims of physical torture for dowry. Of them, 85 died, and 6 committed suicide because of torture. In that year, a total of 409 women were victims of domestic violence. ${ }^{50}$

\subsubsection{Violence Against Domestic Worker and Acid Throwing}

In 2018, as many as 54 women domestic workers became victims of torture. Among them, 4 were victims of rape, 26 were physically tortured, and 18 died of torture and other causes. This year, as many as 22 women were victims of acid attacks, and 1 of them died consequently. ${ }^{51}$

These reports reveal that the human rights of the women are seriously under threat and their rights are not safeguarded. Despite having equal rights provision in the Constitution, women do not have equal share over the property. Though women are entitled to have special protection for their rights, they are contravened enormously in Bangladesh.

\section{Abuses of Children's Rights}

Children are entitled to have special safeguards for their rights. However, their rights are flagrantly contravened in Bangladesh. According to the NHRC monitoring report, 169 children were raped in $2018 .^{52}$ As per ASK report, 1011 children became victims of various forms of torture in 2018. Due to physical torture, murder after rape as well as murder after a failed attempt to rape, killing after kidnapping and disappearance, altogether 283 children were killed, and of them 28 were victims of a mysterious death.

Moreover, as many as 444 children became victims of sexual harassment and rape. ${ }^{53}$ The report uncovers that children's rights are not safeguarded, and they are the frequent victims of breaches of human rights. There is also a lack of child-friendly measures in Bangladesh for the security and benefit of the children.

\section{The response of Bangladesh to the United Nations or Other International Human Rights Bodies}

It is well well-known to the government of Bangladesh that human rights are infringed and not protected. Hence, when the international human rights bodies

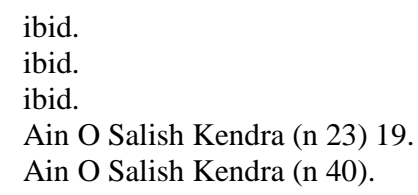


request to visit Bangladesh to understand the real picture of contraventions of human rights, in most cases, the government refuses to allow such a visit. The report confirms that the government did not respond to the request of the UN Working Group on Enforced Disappearances to visit the country. The Office of the UN Resident Coordinator in Bangladesh testified 15 other awaiting requests for UN special rapporteurs to visit the country, including the special rapporteur on extrajudicial killing, summary or arbitrary executions; the special rapporteur on the rights to freedom of peaceful assembly and association; and the special rapporteur on the promotion and protection of human rights and fundamental freedoms while countering terrorism. ${ }^{54}$

As a member of the UN, Bangladesh has the obligation to cooperate with international bodies to ensure peace within and beyond the State. If such international bodies could visit Bangladesh, they might have been acquainted with the real picture of the infringements of human rights. Realizing the human rights situation, they could assist Bangladesh in protecting and promoting human rights appropriately.

\subsection{Report of Human Rights Bodies of Bangladesh}

The human rights report of ASK of 2017 noted that insufficient fund, inadequate support staffs and nominal government's support limit the Commission's effectiveness and independence. ${ }^{55}$ It also remarked that Nasima Begum, former senior secretary of the Ministry of Women and Children Affairs, was appointed the NHRC's Chairman in September 2019. This appointment prompted sharp criticisms from civil society, who questioned the government's selection process, and condemned the Commission's effectiveness and independence as almost all members were former government bureaucrats. ${ }^{56}$ This report reveals that the NHRC is mostly reliant on the government, and simultaneously, it is also unduly influenced by the government. It has also remarked that the appointment procedure of the Chairman and commissioners are not fair and transparent at all. ${ }^{57}$

\subsection{The Universal Periodic Review (UPR) of the UN of Bangladesh}

It is a procedure under which every member of the UN must submit the report of human rights conditions and measures that the government has taken to protect, enforce, and promote human rights within a country. The UPR of 2018, states that Bangladesh's initiative tool to strengthen the national human rights institution (NHRI) is applauded. Michelle Bachelet (High Commissioner for Human Rights) encourages increasing independence and effectiveness of the NHRC, bringing it into

\footnotetext{
Ain O Salish Kendra (n 23).

ibid.

6 ibid.

57 ibid.
} 
full compliance with the Paris Principles, including by ensuring its ability to directly investigate alleged human rights violations perpetrated by the security forces and by making adequate resources available. ${ }^{58}$ Thus, the government of Bangladesh has been instructed to empower the NHRC in full conformity with the Paris Principles. In the third Cycle UPR of Bangladesh, Germany raised three relevant questions. It questioned about what is the current status on the withdrawal of reservations on articles 2 and 16.1(c) of the CEDAW that Bangladesh agreed to; What steps has the Government of Bangladesh undertaken to fight impunity in recorded cases of extrajudicial killings, enforced disappearances, and torture; and what does the Government of Bangladesh intend to do to guarantee freedom of expression in the new Digital Security Act. ${ }^{59}$ These three questions were asked because the infringements of human rights regarding these three areas are very high in Bangladesh. Bangladesh has not replied to these questions appropriately. Considering this report, it is obvious that international communities are not satisfied; rather, they are concerned about the human rights conditions, violations, and abuses in Bangladesh.

\section{Public Opinion as to the Violations of Human Rights}

As human rights are usually breached in Bangladesh, many prominent citizens from diverse experiences have raised their voices as to the abuses of human rights. Habib Zafarullah ${ }^{60} \&$ Mohammad Habibur Rahman ${ }^{61}$ opine that the state of human rights in Bangladesh is far from acceptable, although the concentration on this issue has sharpened significantly. The country's law and order condition portray an awful picture. The situation deteriorated to the extent that police involvement in theft, robbery, and rape frequently appearing in the news. Governments, past and present, have perpetrated severe human rights abuses. ${ }^{62}$ Numan Mahfuj $^{63}$, and Md. Mizanur Rahman $^{64}$ opine that while evaluating human rights and human security scenario in Bangladesh, it is unquestionably evident that fundamental human rights are severely

58 Working Group on the Universal Periodic Review, National report submitted in accordance with paragraph 5 of the annex to Human Rights Council resolution 16/21: Bangladesh (United Nations Human Rights Council 2018) <https://documents-dds-ny.un.org/doc/UNDOC/GEN/G18/050/ 26/PDF/G1805026.pdf? Open Element> accessed 20 July 2020. ibid.

Habib Zafarullah received a Ph.D. in Public Administration from the University of Sydney and currently teaches Political Science and Public Policy at the University of New England, Australia.

Mohammad Habibur Rahman is a Professor of Public Administration at the University of Dhaka.

Habib Zafarullah \& Mohammad Habibur Rahman, Human Rights, 'Civil Society and Nongovernmental Organizations: The Nexus in Bangladesh' (2002), vol. 24, no. 4, Hum. Rts. Q. 1011, the Johns Hopkins University Press, p. 1011-1034. Hein Online, accessed 20 April 2020.

Numan Mahfuj is a lecturer, Department of Public Administration, Jagannath University, Dhaka.

Mizanur Rahman is an Assistant Professor, Department of Public Administration, Bangabandhu Sheikh Mujibur Rahman Science and Technology University, Gopalgonj, Dhaka. 
flouted, leaving people inhumanly unprotected. ${ }^{65}$ Barrister Md. Abdul Halim ${ }^{66}$ and Dr Abdullah A. Dewan ${ }^{67}$ mentioned in a newspaper article that instances of gross human rights violations(HRVs) by law enforcing agencies, local political leaders, elected representatives, private companies, land grabbers, slum evictions and so on are pouring in expressed on a daily and hourly basis. ${ }^{68}$ The former US Ambassador to Bangladesh, Dan Mozena his concern to the NHRC's Chairman of that time Dr Mizanur Rahman that 51 percent of the country's 153 million people are not cognizant of human rights and recommended him to raise people's consciousness (The Daily Sun, 25th July, 2013) ${ }^{69}$ Maliha Khan, a graduate of the Asian University for Women and human rights activist, writes in the Daily Star newspaper that the NHRC Act states that the Commission is an independent statutory body, yet, in many aspects, it acts as a watchdog. While it has the power to investigate complaints of human rights violations, it does little beyond basic fact-finding and writing a report. It does not follow through until official investigations end or are brought to a satisfactory close. She also says that the year 2018 was tumultuous. The quota reform and road safety movements saw students, teachers, and journalists attacked while trying to protest peacefully or covering the protests, pre, and post-election violence, and extrajudicial killings in anti-narcotics drive-by security forces which claimed the lives of around 300 people. $^{70}$ One of the journalists of the Daily New Age newspaper, published an article on 11th February 2020, that the country witnessed a total of 391 alleged extrajudicial killings and that the human rights situation in the country remained quite alarming throughout the year. The public opinion as to the condition of the rule of law is also shocking in Bangladesh. The report demonstrates that in 2020, the position of Bangladesh is 115 out of 128 countries, and the observance of the rule of law in Bangladesh is decreasing every year. ${ }^{71}$ This report is prepared based on public opinion. Thus, the opinion of the public reveals that the contraventions of fundamental rights and human rights are ever-increasing in Bangladesh.

65 Numan Mahfuj and Md. Mizanur Rahman, 'Ensuring Human Security in Bangladesh: Role of National Human Rights Commission (NHRC)' <https://www.academia.edu/37437897/Ensuring Human_Security_in_Bangladesh_Role_of_National_Human_Rights_Commission_NHRC> accessed 20 April 2020.

Md. Abdul Halim is an Advocate in the Supreme Court of Bangladesh.

67 Dr. Abdullah A. Dewan is a Professor of Economics, Eastern Michigan University, USA.

68 Md Abdul Halim and Abdullah A Dewan, 'Is National Human Rights Commission (NHRC) A Show and Tell Institution Part II?' The Daily Sun, (Dhaka, 27 July 2013) <https://www.academia.edu/ 36846951/Is_National_Human_Rights_Commission_Nhrc_A_Show_And_Tell_Institution_Part-I> accessed 20 April 2020.

69 ibid.

70 Maliha Khan, How independent and effective is the NHRC, 'Your Right To Know' The Daily Star, (Dhaka, 17 July 2019) <https://www.thedailystar.net/star-weekend/cover-story/human-rights-howindependent-and-effective-the-nhrc-1769992> accessed 25 April 2020. 


\section{Judicial attitude towards the NHRC}

The NHRC has the authority to proceed to the court to get redress for the infringements of human rights on behalf of victims. In Children's Charity Foundation Bangladesh Vs. NHRC ${ }^{72}$, popularly known as the Khadiza torture case, the petitioner alleged that the torture and abuse of domestic worker Khadiza Akhter was perpetrated by her employer in the Mirpur of Dhaka. On 6th December 2013, police rescued her from her employer's house and got her admitted to Dhaka Medical College Hospital with injuries on different parts of her body. Before filing the writ petition, a letter was sent to the NHRC to take action against the violators of human rights by the Children's Charity Foundation Bangladesh, but it did not take any significant step at all. The High Court Division (HCD) of the Supreme Court of Bangladesh, in its observation, directed the NHRC to raise any matters before the court, if the government authorities concerned do not comply with the Commission's recommendations. The court also pronounces that the NHRC is not doing enough to protect the victim of human rights violations. The HCD also opined that the rights body's "negligence" is frustrating. ${ }^{73}$ It is pertinent to comment that the petitioner raised the issue that due to the defective appointment procedure, the NHRC has become a club of former bureaucrats and for which it cannot go against the government's agenda. ${ }^{74}$ The respondent, Fauzia Karim, who was also a member of the NHRC, argued that the NHRC does not have enough power to protect human rights within the NHRC Act. ${ }^{75}$ From the arguments of the parties and opinions of the court, it may be assumed that the NHRC has neglected to protect and promote human rights in Bangladesh due to the lacunae within the NHRC Act.

\section{Comparative Analysis of Human Rights Institution of Bangladesh, India, Nepal, and South Africa}

\subsection{Comparison between Bangladesh and India}

There is a significant deficiency in the appointment procedure of the Chairman and members of the NHRC of Bangladesh. The above discussion reveals that even a person who does not have any legal expertise in human rights may be appointed as the Chairman and members of the Commission. ${ }^{76}$ Consequently, the appointed office bearers of the Commission may not realize the real meaning of human rights and their proper enforcement mechanisms. Thus, the lack of required legal knowledge in human rights and their enforcement mechanisms may indirectly hinder them from performing their duties properly and effectively. Whereas, the Protection of Human

\footnotetext{
Writ Petition No 16386 of 2018, Judgment on 11.11.2019(HCD), judgment has not been yet reported.

Maliha Khan (n 70).

Writ Petition No 16386 of 2018 (n 72), para 4.10.

ibid.

NHRC Act 2009 (Bangladesh), s 6(2).
} 
Rights Act 1993 of India stipulates that the Chairman and two members of the Commission must be appointed from persons who have been or are Chief Justice or Judges of the Supreme Court or High Courts of India and another two members shall be appointed from persons having knowledge of or practical experience in, the matters relating to human rights. ${ }^{77}$ Thus, India has emphasized more on the legal background in selecting Chairman and members of the NHRC, perhaps considering the above consequences.

This Act of India, in contrast, provides for the institution of Human Rights Courts for speedy trial of offenses arising out of contravention of human rights. ${ }^{78}$ As human rights are the most crucial and specialized area of jurisprudence, it entails special protection. It is plausible that a special court may protect and enforce breaches of human rights appropriately and effectively. The NHRC Act does not have any provision like this. Consequently, the sufferers of abuses of human rights do not get proper remedies in Bangladesh.

\subsection{Comparison between Bangladesh and Nepal}

Although as per the NHRC Act 2009, the NHRC is an independent statutory body $^{79}$, in reality, it is not as independent as is necessary for its proper and independent functioning. For several purposes, including those of finances, it has to depend on the government and other agencies. ${ }^{80}$ In contrast, the Constitution of Nepal provides that the Commission is the Constitutional body. ${ }^{81}$ As the Constitution is the supreme law of a country, provisions of it are given prime importance, and everybody, including the government cares about the Constitutional mandate. It is thought that a Constitutional body is more powerful than the statutory body due to its Constitutional status. A Constitutional body is only answerable to the Constitution. Legally, a Constitutional body is given a higher rank than a statutory body. Thus, a Constitutional body can act more effectively, appropriately, and independently than the statutory body.

The Constitution of Nepal authorizes that the Commission in accomplishing its functions and duties may use the authority to order compensation to the victims of human rights infringements. ${ }^{82}$ The NHRC of Bangladesh might have the legal power to award compensation to the victims of human rights violations as interim relief. However, there is no such provision in the NHRC Act to award compensation to sufferers for abuses of human rights instead it has the power to recommend to the government to award aid (not compensation) to the victim as an interim relief during

\footnotetext{
Protection of Human Rights Act 1993 (India), s 3(2).

ibid, $\mathrm{s} 30$.

NHRC Act 2009 (Bangladesh), s 3(2).

ibid, s 24(4)(a).

Constitution of Nepal 2015, Part 25, art 248.

ibid, art 249(3)(d).
} 
the period of investigation or inquiry. ${ }^{83}$ It, in effect, means that aid is possible only when the government thinks it fit and proper. Thus, the aid measure is dependent on the mercy of the government. This factually transfers the balance of convenience to the government and therefore makes the NHRC actions conditional upon the satisfaction of the former. Thus, the actual power to decide aid belongs to the government. This hinders the NHRC to ensure justice for the victim.

The Constitution of Nepal has not excluded any authority from the purview of its Commission. ${ }^{84}$ However, the NHRC Act of Bangladesh stipulates that notwithstanding anything contained in section12 (1), the following matters shall not be included into the functions or duties of the Commission; issues relating to the cases being tried before a court; or any issue relating to the service matters of the public servants of the Republic and any employee engaged in the service of a statutory public authority which is triable in any tribunal established under the Administrative Tribunals Act, 1980(Act VII OF 1981) ${ }^{85}$ It may be assumed that the authorities who are beyond the jurisdiction of the NHRC deal with several crucial human rights issues. Keeping them out of its jurisdiction in such areas, where a right can be infringed in any form not only limits the power of the NHRC but also implies that some breaches, even if they occur, stand outside the jurisdiction of the Commission forever. This somewhat indemnity is dangerous for a human rights culture as if it affords a kind of permission for some infringements to continue.

\subsection{Comparison between Bangladesh and South Africa}

As argued above, the NHRC is, in effect, merely a recommendatory body. It cannot pass any mandatory decision or direct the government to modify or change the draft bill of legislations that do not comply with the human rights obligation of Bangladesh. It is only authorized to make recommendations to the government for taking appropriate measures, and the government is not legally obligated to comply with recommendations forwarded by the Commission. In comparison, the Constitution of South Africa stipulates that the Commission possesses the power to take steps to guarantee appropriate redress for human rights violations. ${ }^{86}$ Thus, the South African Commission has extensive authority to implement human rights by offering a proper remedy to victims. Whereas the NHRC of Bangladesh does not have any authority over anyone for the enforcement of human rights or the execution of its decision. It also has no power to take binding initiatives for the implementation and protection of human rights. The Constitution of South Africa also provides that the commission is a Constitutional body ${ }^{87}$ In contrast, the same is a statutory body in Bangladesh.

\footnotetext{
NHRC Act 2009 (Bangladesh), s 19(2).

Constitution of Nepal 2015, art 249.

NHRC Act 2009 (Bangladesh), s 12(2).

${ }^{86}$ Constitution of South Africa 1996, s 184(2)(b).

87 ibid, s 184.
} 
The South African Commission has a mandate to get a report from each department of government every year to uncover what they have done to promote human rights in their work. ${ }^{88}$ This is a vital provision that paves the way for the Commission to overview the functions of each department of government and prepare human rights assessment based on that report. Consequently, each department of government may be more alert in the fulfillment of human rights obligations and in developing human rights culture. In India, obeying the orders of the Commissions has become a convention though it is still a pretty borderline case. ${ }^{89}$ In Bangladesh, the NHRC has no authority to ask for report or even the reason for the non-compliance of its recommendations.

\section{Lacunae in the NHRC Act}

The NHRC Act, if we consider it as a statement of the State, in the fulfillment of its international commitment to protect and promote human rights and human development, its linguistic mandates portray the pros and cons within it. If these are assessed against any practical parameter, a near correct result of the legal provisions can be assumed. The GANHRI (Global Alliance of National Human Rights Institutions) categorizes the national human rights institutions on the basis of their performance and compliance of its enabling Act with the Paris Declaration. Its report confirms that the NHRC of Bangladesh is now in the 'B' category. ${ }^{90}$ It also reveals few lacunae and limitations of the existing NHRC Act of Bangladesh, which are obstacles for the NHRC to be elevated to 'A' category which are as follows:

- inadequate definition of Human Rights;

- lack of transparency in the selection process of the Chairman and members;

- limitation in enjoying full economic freedom;

- and limited jurisdiction in investigating violations of human rights by law enforcement agencies i.e., police and security forces. ${ }^{91}$

This report uncovers that the NHRC cannot do well in protecting and promoting human rights due to some inherent lacunae within the NHRC Act. The NHRC Chairman argues that the NHRC does not have enough power to fight against all the facets of human rights violations $(\mathrm{HRVs}) .^{92} \mathrm{He}$ routinely grumbles that the

88 South African Human Rights Commission Act 2013, preamble; Constitution of South Africa 1996, s 184(3).

89 A H Monjurul Kabir, ‘A National Human Rights Commission for Bangladesh' (December 1999) 18 Focus<http://www.hurights.or.jp/archives/focus/section2/1999/12/a-national-human-rightscommission-for-bangladesh.html> accessed 14 January 2020.

90 Ain O Salish Kendra, 'Report on Civil Society Dialogue with National Human Rights Commission Bangladesh' (n23).

91 ibid.

92 Halim and Dewan (n 68). 
Commission lacks any authority to take action for HRVs by disciplinary forces. ${ }^{93}$ Thus, because of shortcomings in the NHRC Act, the NHRC is failing to protect human rights adequately. It is evident that the NHRC Act is by and large a monistic instrument that very improperly burdens the NHRC with responsibilities for which there are no guarantees in the Act of mutual or corresponding obligations. This absence of counterbalancing formulation in the provisions of the Act makes most of its claims, statements somewhat phony. This is apparent, especially when compared to a similar yet functionally better model. The generality of such asymmetries significantly weakens the normative strength of the law and efficacy of the NHRC. A glimpse of this imbalance is described below:

\subsection{Flaws in the Definition of "Human Rights"}

The definition of human rights given in the NHRC Act is flawed. As discussed above, the definition is very thin, and it does not include all facets of human rights. It also does not cover the universal character of human rights because it includes only Constitutionally guaranteed human rights and recognized human rights embodied in international human rights instruments, which have been ratified by Bangladesh as well as enforceable by the existing laws. ${ }^{94}$ It disregards the fundamental principles of state policies, as mentioned in the Constitution of Bangladesh, which are also critical human rights issues. It expressly focuses more on civil and political rights than social, economic, and cultural rights. "Human rights those are declared under different international human rights instruments ratified by Bangladesh and are enforceable by the laws of Bangladesh". ${ }^{95}$ This part of the definition has imposed limitations on the international standard, and the Commission can only exercise its jurisdiction on those human rights, which are recognized and enforceable by the State, but not all internationally recognized rights. ${ }^{96}$ Hence, the cardinal philosophy of human rights, as discussed earlier, has not been addressed adequately by this definition. It is settled that human rights do not require recognition or ratification of any country to be enforced and call for Constitutional recognition of those rights; instead, it covers all rights recognized by the international human rights instruments. The enforceability of those rights also does not depend on the domestic court as required by the NHRC Act.

\subsection{Multifaceted Institutional Dependencies of the NHRC}

Institutional independence is sine qua non to make any institution free and useful. It implies that an independent institution shall be free from all sorts of dependencies, pressures, or influences from other institutions of the government. As per the Paris Principles, for a NHRI to be truly independent, it must be financially solvent and able

93 ibid.

94 NHRC Act 2009 (Bangladesh), s 2(f).

95 ibid.

96 NHRC, Rahmat Ullah and Bayazid Hossain, 'Study Report on JAMAKON: Critique’ p 13 
to act independently concerning budget and expenditures. ${ }^{97}$ NHRIs are often ineffective because they lack resources. Control over their funding should be independent of the government. Governments and legislatures should guarantee that NHRIs receive adequate funds to perform all the functions set out in their mandates. ${ }^{98}$ However, the NHRC of Bangladesh for several purposes, including those of finances, is directly dependent on the government and other agencies. ${ }^{99}$ The NHRC Act requires that the fund of the NHRC shall come from government grants and grants provided by the local authority. ${ }^{100}$ The term local authority has not been defined in this Act. At present, the government's allocation is coming through the national budget. This should continue and needs to be guaranteed through law. ${ }^{101}$ The report of the NHRC claims that "the NHRC gets budgetary allocation from the government, but insufficient. The exclusion of the NHRC's annual expenses from the national budget has been marked as negligence of the government to the Commission. It is meaningless to think over the independence of the NHRC without self-budgetary power. It cannot implement its plan due to shortage of funds and government dependency". ${ }^{102}$ In exercise of power, execution of decision, technical assistance, and performance of obligations, the NHRC has to depend on foreign aid and government significantly. The dependency of the NHRC on the project has gone into such an interior that it has to hire international consultants for almost all its significant tasks, including essential functions like baseline survey of the human rights situation, formulating five years strategic plan, and other operational procedures. ${ }^{103}$ Simultaneously, the government does not allocate the total contribution of the donors for the NHRC's activities. For example, in 2011, the NHRCCDP contributed USD 1,400,000, but the Government allocated a mere USD 196,250. ${ }^{104}$ Thus seemingly, the NHRC does not enjoy full control over finance. One of the functions of the NHRC is to review the factors, including acts of terrorism that inhibit the safeguards of human rights and to make recommendations to the government for

97 International Council on Human Rights Policy, Assessing the Effectiveness of National Human Rights Institutions (OHCHR 2005) 8. This report is co-published by the International Council on Human Rights Policy and the Office of the United Nations High Commissioner for Human Rights <https://www.ohchr.org/Documents/Publications/NHRIen.pdf> accessed 20 February 2020.

${ }^{01}$ Mizanur Rahman and others (eds), Annual Report (National Human Rights Commission Bangladesh 2010)<http://nhrc.portal.gov.bd/sites/default/files/files/nhrc.portal.gov.bd/page/cb8edec9_5aee_4b04 _bf2a_229d9cd226a0/Annual\%20report\%202010.pdf> accessed 26 October 2019.

102 Ullah and Hossain (n 96).

${ }^{103}$ NHRC conducted a baseline survey (2011) having supports form UNDP, Danish International Development Agency (DANIDA), Swiss for Development and Cooperation (SDC) and Swedish International Development Agency (SIDA). Cited in NHRC Annual Report (n 26) 55.

104 Ain o Salish Kendra (ASK) and Human Rights Forum, Bangladesh, Bangladesh: National Human Rights Commission is in Critical Juncture of Hype versus Real Action (ANNI Report-2012, Dhaka) 25. cited in NHRC Annual Report' (n 26) 56. 
their appropriate remedial measures. ${ }^{105}$ This provision implies that the NHRC has to rely on the government to take remedial measures against infringement of human rights. In case of violations of human rights by law enforcement agencies, the NHRC can only ask for a report from the government. ${ }^{106}$ The government has no corresponding obligation to send the report in reply to the NHRC under the NHRC Act. The NHRC has delivered statements, given recommendations and investigated the violations of human rights for its prevention, despite that unlawful arrest, forced disappearance, extrajudicial killing, torture in police custody and other cases of violation of human rights are increasing alarmingly which is evident from the report made by the NHRC and UNDP. ${ }^{107}$ Further, the NHRC has no separate secretariat. The Ministry of Law, Justice and Parliamentary Affairs acts as the secretariat of it, which is likely to hinder the NHRC from functioning independently. Thus, due to the lack of institutional independence, NHRC is powerless to execute its own decisions and mandates.

\subsection{Inappropriate Appointment Procedure of Office Bearers}

As discussed above, even a person who does not have any legal acumen as to human rights may be appointed as Chairman and member of the Commission under the NHRC Act. ${ }^{108}$ Due to the flaws in the selection process, the Chairman and most members of the NHRC may be appointed from persons who have a direct or indirect connection with the government. The civil society does not have an opportunity to be involved in this process. A transparent appointment procedure is necessary to ensure the independence of the NHRC. Appointment processes are one of the most important ways to guarantee the freedom, diversity, and accessibility of NHRIs. A direct appointment by the executive branch of government is undesirable. The appointment procedure should be open and translucent. ${ }^{109}$ Because of unfair appointment provision in the NHRC Act, the appointment procedure is swayed by the government. Apart from this, of the seven commissioners, only Chairman, and one commissioner are full-time members, and the rest of the commissioners are appointed on an honorary basis. ${ }^{110}$ However, if all members were appointed as full-time members, they could spend more time participating more efficiently in the affairs of the NHRC and contribute their potentials to the development of the NHRC.

\subsection{Limited Mandates without Power to Enforce}

As discussed above, the NHRC can only inquire or investigate any violation of human rights. It has no power to take any obligatory actions or decisions based on its

\footnotetext{
${ }^{105}$ NHRC Act 2009, s 12(1)(e).

106 ibid. s 18.

107 National Rights Commission Bangladesh (n 26).

108 NHRC Act 2009 (Bangladesh), s 6(2).

109 National Rights Commission Bangladesh (n 26).

110 NHRC Act 2009 (Bangladesh), s 5(2).
} 
investigation or inquiry report. There is also no provision in the NHRC Act which makes the government bound to take into account the inquiry or investigation report submitted by the NHRC. In praxis, acceptance of such a report depends on the will of the concerned agency of the State. It means that if the State does not accept such investigation report, it becomes factually pointless and, therefore, the situations it addressed or, the remedies it offered are more likely to remain dormant forever.

\subsection{Lack of Compensatory Measures}

The NHRC might have the legal authority to award compensation to the victim of abuses of human rights as interim relief. Both the commissions of Nepal and South Africa have such kind of jurisdiction. A right without a remedy is meaningless. The current human rights jurisprudence advocates that every victim of human rights violations shall have the enforceable right to have compensation. For example, the victim of arbitrary arrest is entitled to compensation. ${ }^{11}$ Thus, lack of this power hinders the NHRC from ensuring justice for the victim who suffers pecuniary loss due to the violations of human rights.

\subsection{Recommendatory Body}

As discussed above the NHRC is, in effect, merely a recommendatory body. NHRIs should have the power to monitor the extent to which relevant authorities shall follow their advice and recommendations. Monitoring should become a consistent practice. ${ }^{112}$ NHRIs usually have no direct authority to enforce their recommendations. To have such ability is generally regarded as being contrary to justice because NHRIs would combine both inquisitorial and quasi-judicial functions. ${ }^{113}$ At the same time, relevant authorities should be required to respond within a specified time to recommendations or contrary findings that national institutions make. ${ }^{114}$ Thus, to be an influential institution, the NHRC should have the authority to get report from the government after sending recommendations to it.

\subsection{Segregation of Some Crucial Areas from Sphere of the NHRC}

As discussed above, some authorities have been kept outside the jurisdiction of the NHRC. This kind of indemnity is a threat to the violations of human rights. NHRIs mandated to receive complaints should have broad powers to deal with them. As with their monitoring role, no relevant public body should be excluded from their jurisdiction. ${ }^{115}$ Thus, no public body, including law enforcement agency and army, should be kept beyond the purview of the NHRC.

\footnotetext{
111 ICCPR, art 9(5).

${ }^{112}$ International Council on Human Rights Policy (n 97).

113 ibid, at 21-22.

114 ibid.

115 International Council on Human Rights Policy (n 97) 20.
} 


\subsection{Inability to File Case against Government}

Another fundamental flaw that is innate in the NHRC Act is that the Commission has no authority to file any case against the government. ${ }^{116}$ Whereas, in India and New Zealand, the commissions are empowered to file cases against the government taking prior permission from the Attorney General. ${ }^{117}$ Theoretically, it is implausible to imagine a human rights violation without counting the government's involvement in it. Again, any redress or remedy for breach of human rights is possible only by the government (or, so to say, the State). The theoretical makeup urges that the State's onus is central for human rights. Thus, if the Commission is unable to file case against the government, it may frustrate the ultimate objectives of the Commission.

\section{Impact of flaws on SDGs}

There is a direct relationship between sustainable development and human rights. It is implausible to ensure sustainable development without enforcement and implementation of human rights. ${ }^{118}$ Each goal of the SDGs is, directly and indirectly, connected and dependent on the implementation and enforcement of human rights. Amartya Sen, a former Nobel laureate of economics, emphasized on democracy and human rights as keys to sustainable development. ${ }^{119}$ NHRIs are supposed to be independent State institutions that operate from a neutral and robust position among the State, civil society, and international institutions. Their monitoring mandates give them a unique position to act as both watchdog and advisor, to uphold the human rights embedded in the SDGs, particularly SDG $16 .{ }^{120}$ NHRIs are crucial components of the good governance and institutional accountability architecture that is necessary to achieve the SDGs. ${ }^{121}$ They are also essential elements of the accountability architecture necessary for ensuring peaceful and inclusive societies with access to justice for all. ${ }^{122}$ In March 2019, the Human Rights Council (HRC) conducted an

116 NHRC Act 2009 (Bangladesh), s 29.

117 ICC, 2014, 'Chart of the Status of National Institutions'. [Online], <http://www.ohchr.org/ Documents/Countries/NHRI/Chart_Status_NIs.pdf > accessed 25 April 2020.

118 Declaration on the Right to Development, Adopted by General Assembly resolution 41/128 of 4 December 1986, preamble <https://www.ohchr.org/en/professionalinterest/pages/righttode velopment.aspx> accessed 25 April 2020.

119 Joseph Stiglitz and Amartya Sen, 'the Sustainable Development Goals, a Special UN Summit' $<$ https://www.wider.unu.edu/publication/joseph-stiglitz-and-amartya-sen-sustainable-developmentgoals> accessed 27 May 2020.

120 NHRIs and the Sustainable Development Goals, GANHRI <https://nhri.ohchr.org/EN/Themes/ Sust Dev Goals/Pages/default.aspx> accessed 21 April 2020.

${ }^{121}$ Rachel Murray, Francesca Thornberry, and Gilford Kimathi, 'African National Human Rights Institutions and Sustainable Development: An Overview Of Good Practice' This publication is a joint initiative of the Danish Institute for Human Rights and the Working Group on the 2030 Agenda for Sustainable Development and the African Agenda 2063 of the Network of African National Human Rights Institutions, p, $9,<$ https://www.humanrights.dk/sites/humanrights.dk/files/media/dokumenter/human rights_and_development/nhris_and_sdg_work_in_africa_report.pdf> accessed 25 May 2020.

122 ibid, at 9 . 
intersessional half-day consultation to swap experiences and practices on how NHRIs are working to support the establishment and maintenance of inclusive societies and the implementation of the 2030 Agenda. The meeting concluded that NHRIs use their unique mandate, role, and functions, which allow them to promote all human rights and serve as a bridge between national stakeholders, thereby contributing to the meaningful participation and cooperation of all actors, which is necessary for achieving the SDGs. ${ }^{123}$ The core philosophy of the establishment of the NHRC in Bangladesh is to play a role as a watchdog for upholding human rights. In reality, all the reports of human rights violations reveal that this institution has to a large extent, failed to do so due to the inherent lacunae in the NHRC Act 2009. Despite the existence of the NHRC, unlawful arrest, forced disappearance, extrajudicial killing, torture in private and public custody, rape, child torture, violations of women rights, rights of marginalized communities, labor rights and other types of human rights abuses are increasing alarmingly which is evident from the discussed reports of human rights violations. Therefore, the ultimate object of the formation of the NHRC is being frustrated, and Bangladesh is deviating from the practice of human rights culture because of such flaws in the NHRC Act. Consequently, Bangladesh has failed to satisfy its obligations of protection, promotion, and enforcement of human rights under the UN Charter, ICCPR, ICESCR, CEDAW, CRC, CAT, Paris Principles, and other international human rights Conventions. Ultimately, it is failing to fulfill obligations under the SDGs as well. The SDGs are designed to "leave no one behind", and the agenda integrates cross-cutting human rights principles such as participation, accountability, and non-discrimination. ${ }^{124}$ However, owing to violations of human rights and the ineffectual role of the NHRC in protecting, enforcing, and promoting human rights and development, some classes or groups of people are lagging behind day by day.

As discussed above, Bangladesh's position in the world rule of law index is continuous to be years after years. Bangladesh's NHRC holds 'B' ${ }^{125}$ status, as accorded by the GANHRI (Global Alliance of National Human Rights Institutions) twice, once in 2011, and then in 2015. The Commission has been assessed on how compliant it is with the Paris Principles, the international benchmark for NHRIs. Both times, the NHRC of Bangladesh has been denied ' $\mathrm{A}^{126}$ status, which means it does not fully comply with the principles. However, neighboring countries Nepal and India have obtained ' $A$ ' status. ${ }^{127}$ Thus, NHRC is losing its reputation in the international arena, which has a massive impact on international relations and economic development. For example, after the collapse of Rana Plaza (a building of garments

123 Ibid, at 11.

124 NHRIs and the Sustainable Development Goals, GANHRI (n 120).

125 NHRC gets 'B' status when it complies with the Paris Principles partially.

126 NHRC gets 'A' status when it complies with the Paris Principles entirely.

127 Maliha Khan (n 70). 
factory which collapsed due to breach of building code resulting in death and injuries of thousands of laborers therein), the international buyers decided that they would not buy garment's products from Bangladesh if labor rights are not ensured and protected in Bangladesh. ${ }^{128}$ At the time of engaging in international relations and cooperations, many countries investigate the human rights condition and the world rule of law index. Goal 16 of SDGs requires that every State shall promote peaceful and inclusive societies for sustainable development, provide access to justice for all and build effective, accountable, and inclusive institutions at all levels. It implies that a developed and strong institution is necessary to prevent violations of human rights. The reports of violations of human rights implies that lack of effective, accountable, and inclusive institutions, are responsible for breaches of human rights.

Consequently, Bangladesh is facing obstacles in fulfilling the goals of sustainable development. The NHRC of Bangladesh could play a crucial role in protecting and preventing violations of human rights if it would have been an accountable and influential institution. However, owing to inherent flaws in the NHRC Act, the NHRC of Bangladesh cannot act as a watchdog for the prevention of violations of human rights. The SDGs monitoring framework explicitly recognizes the existence of an independent NHRI that is compliant with the Paris Principles as an indicator for SDG 16 on peace, justice, and strong institutions (indicator 16.a.1). ${ }^{129}$ Without instituting an effective, accountable, and inclusive institution to provide access to justice for all, it is impossible to attain sustainable development goals. NHRIs can make linkages between human rights and SDGs commitments and standards. ${ }^{130}$ The UN Secretary-General urges countries to accelerate the pace of progress to put in place NHRIs compliant with the Paris Principles. ${ }^{131}$

The goals of SDGs will not be fully achieved by the State until fundamental human rights are realized, enforced, and protected. Therefore, to achieve the goals of SDGs, strengthening the NHRC is a dire necessity.

\section{Recommendations}

Glancing on the different flaws of the NHRC Act make it urgent to prescribe a feasible model. Therefore, it may be recommended that the NHRC requires an intelligent and efficient structure supported by well-drafted, pro-human rights, and

128 Charles Kenny, 'Why You should not stop buying from Bangladesh' (Bloomberg, May 6, 2013) $<$ https://www.bloomberg.com/news/articles/2013-05-05/why-you-shouldnt-stop-buying-frombangladesh> accessed 2 November 2019. NHRIs and the Sustainable Development Goals, GANHRI (n 120) 10.

${ }^{130}$ Ibid, at 11.

131 'Enabling The Implementation of the 2030 Agenda through SDG 16+, Anchoring peace, justice and inclusion'(Global Alliance, July 2019) <https://nhri.ohchr.org/EN/Themes/SustDevGoals/ Documents/Global\%20Alliance,\%20SDG\%2016+\%20Global\%20Report.pdf> accessed 20 May 2020. 
comprehensive law. The present form of the NHRC Act provides mandates which are more cosmetic than substantive. It, therefore, is argued that the Act of 2009 requires a thorough revision to make the NHRC genuinely worthwhile. To that end, the following recommendations can be considered-

\subsection{Amendment of Definition of Human Rights}

The term 'Human rights' has not been appropriately addressed and defined in the NHRC Act. The Constitution of Nepal 2015 has not imposed any restriction on the definition of human rights; instead, it has mentioned the term human rights. Thus, the Commission of Nepal can protect and promote all human rights irrespective of whether the Constitution recognizes or whether those rights are enforceable by law or not. Therefore, the definition of human rights should be amended in such a way to include all human rights recognized by international human rights instruments.

\subsection{Recognition of the NHRC as a Constitutional Body}

Like Nepal and South Africa, if the NHRC of Bangladesh becomes an independent Constitutional body, it may perform its duties more efficiently and appropriately. Thus, the government should take a step to assimilate provisions in the Constitution of Bangladesh to recognize the NHRC as an independent Constitutional body. It may make the NHRC a more independent, efficient, and workable institution for the promotion, protection, and enforcement of human rights and human development.

\subsection{Safeguard Institutional Independence}

The government may include a provision in the NHRC Act that the NHRC shall be independent and free from the interference of all governmental institutions, political bias, and other bodies in discharging its functions. An effective national institution is one which is authorized to act outside the purview of political parties and all other entities and situations which may be in a position to affect its work. ${ }^{132}$ It should also have the authority to make its own budget and take direct grants from any national or international donors without any kind of intervention and approval from the government. The government may insert provisions in the NHRC Act like the South African Commission that the Commission shall be subject only to the Constitution and other organs of the State will be obliged, through legislative and other measures to assist and protect the commission to ensure its independence, neutrality, dignity, and effectiveness. ${ }^{133}$ These agencies shall also be barred from interfering with its functioning. ${ }^{134}$ These provisions may be good enough to guarantee the independence of the NHRC both legally and theoretically.

132 Arun K. Palai, National Human Rights Commission of India: Formation, Functioning and Future Prospects (Atlantic Publishers 1998) 155.

133 Final Constitution, s 181(3), cited in Susant Kumar Kanungo, National Human Rights Commission in India and South Africa: A Comparative Analysis (Manak Publication 2015) 289.

134 Ibid, s 181(4). 


\subsection{Amendment of Appointment Procedure}

There should be provisions in the NHRC Act that at least the Chairman and one member of the Commission must be appointed from persons having the legal experience in the field of human rights with other qualifications. Otherwise, because of the ignorance of human rights jurisprudence, they might end up making decisions that are inconsistent with established human rights norms and cultures. It is a dire necessity to include criteria that help to ensure independence. For example, civil servants or political party officials may be declared as disqualified to be appointed as the Chairman and members of the Commission. ${ }^{135}$ Furthermore, it may also require legal expertise like India and so an appointee must be a person who is or has been a Judge or has been qualified to be a Judge of the Supreme Court.

\subsection{Increase the Number of Members in the NHRC}

It is exceedingly difficult to accomplish such varied and extensive functions of the NHRC by only one permanent Chairman and member. The Commission would be more effective if it were comprised of five or seven full-time members. ${ }^{136}$ Thus, like India and to comply with the Paris Principle, it is necessary to appoint at least five permanent members in the NHRC.

\subsection{Power to Enforce the Recommendations}

The legislature may insert a provision that the NHRC shall have the authority to get explanations from the government when it ignores its recommendations. Alongside this, the NHRC must have mandates to collect reports on human rights situations or actions promoting human rights from different organs of the State like the South African's Commission. This may be an excellent provision to pave the way for the Commission to overview the functions of each department of the government to gear up human rights assessment based on that report. Consequently, each department of government will be more alert in the fulfillment of its human rights obligations and in developing human rights culture.

\subsection{Widening the Scope of the NHRC Act}

Every State agency bears the risk of violation of human rights in their day-to-day affairs. Hence, keeping some of them outside the purview of the NHRC fairly allows some violations to occur despite their innate illegality. This is clearly contradictory to the prevailing norms of law and human rights jurisprudence. Therefore, the Parliament may insert a provision in the NHRC Act that all the authorities shall fall within the jurisdiction of the NHRC.

135 NHRC, 'Annual Report' (n 101) 14.

136 David A. Johnson and Nizamuddin Al-Hussainy, (JAMAKON) 'Final Evaluation of the UNDP Capacity
Development Project' (BHRC-CDP) May 2010 December 2014, <https://www. slideshare.net/drnizamalhussainy/final-evaluation-of-the-bnhrc-11-mar-2015> accessed 20 March 2020. 


\subsection{Special Court or Tribunal for Human Rights and Compass of Mediation}

Like the Protection of Human Rights Act, 1993 of India, the NHRC of Bangladesh may include provision for the establishment of human rights courts to provide speedy trial of offenses arising out of violation of human rights. ${ }^{137}$ It may also include in the Act that the Judges of the said court shall be appointed from the persons who have legal knowledge, acumen, experience, and strong commitment to human rights. Human rights law is a special branch of law. Therefore, in addition to the Human Rights Courts, the Commission may have its tribunal for the trial of the violations of human rights like other Commission of the country. Under the Bangladesh Energy Regulatory Commission Rules 2016, the Bangladesh Bar Council Order 1972, and the Customs Act 1969, those respective commissions have the authority to set up tribunals to resolve disputes arising out of their concerned issues.

\subsection{Appointment of Special Prosecutor}

Like the Protection of Human Rights Act, 1993 of India, the NHRC Act should have a provision that special public prosecutors shall be appointed for filing and representing cases before the Human Rights Court. ${ }^{138}$ There may also be a provision in the NHRC Act that pro-people separate bodies of public prosecutors or advocates who have vast knowledge and an inviolable commitment to human rights, may be created to fight in other courts on behalf of the NHRC for the proper and adequate relief for victims of violations of human rights.

\subsection{Power to File Case against the Government}

As mentioned above that discounting the government's failure, it is theoretically or factually impossible to frame a case of human rights violation. Thus, to exclude the government from any charge, especially in case of human rights violations, is a serious threat to enforce human rights. Therefore, necessary provisions must be inserted in the NHRC Act to authorize the NHRC to file cases against the government.

\subsection{Restriction to Reappointment of the Chairman of the NHRC in any Government Post after Retirement}

The NHRC Act does not have any provision that the Chairman will be disqualified to be appointed in any government's office after his retirement from the NHRC. This may encourage him to act in favor of the government to get appointed in any other lucrative post of the government after his retirement. Thus, the NHRC Act may insert a provision that after the completion of tenure from NRHC, the Chairman shall be disqualified to be appointed in any other government's post.

${ }^{137}$ Protection of Human Rights Act 1993 (India), s 30.

138 ibid, s 31. 


\subsection{Power to Take Precautionary Measures}

The NHRC cannot issue any preemptive order to restrain the possibility of violations of human rights. Inter-American Human Rights Commission (IAHRC) has jurisdiction to take or issue precautionary measures in severe or urgent situations of violations of human rights to prevent irreparable harm to any person.139 Like the IAHRC, provision may be inserted in the NHRC Act to authorize it to take or issue a preemptive action or order to restrain the prospective serious or urgent violations of human rights.

\subsection{Power to protect violations of human rights by the business corporation}

As business corporation and other corporate bodies has a dominant position in every State in the contemporary world, it may violate human rights in many ways. They may violate labor rights, have adverse effects on the environment and endanger the right to safe health as well. It is assumed that corporations maintain very close connection with the government. Thus, they may be exempted from the liability of violations of human rights by using their influence. Thus, this issue needs special attention.

For this reason, the UN has formulated guiding principles in this regard. The United Nations Guiding Principles on Business and Human Rights (UNGPs)140 consist of 31 principles and set out expectations of States and companies about how to prevent and address adverse impacts on human rights by business. 141 They rest on three inter-related pillars, also jointly called the 'Protect, Respect, and Remedy' framework:

- The state duty to protect against abuses by third parties, including business, through effective policies, legislation, regulation, and adjudication.

- The corporate responsibility to respect and avoid infringing human rights of others and address adverse human rights impacts in which companies are involved.

- Ensure access to victims of corporate human rights abuses to effective remedies - judicial and non-judicial - provided by States and companies. ${ }^{142}$

NHRIs can play a key role in this regard. Professor John Ruggie commented that "The actual and potential importance of these institutions cannot be overstated. Where NHRIs are able to address grievances involving companies, they can provide a means to hold business accountable. NHRIs are particularly well-positioned to provide processes that are culturally appropriate, accessible, and expeditious [and] can provide information and advice on other avenues of recourse to those seeking

139 Rules of Procedure of the IACHR, art 25, <https://www.oas.org/en/iachr/decisions/aboutprecautionary.asp> accessed 12 May 2020.

140 United Nations Guiding Principles on Business and Human Rights: <https://www.ohchr.org/ documents/publications/GuidingprinciplesBusinesshr_eN.pdf $\geq$ accessed 10 May 2020.

141 ibid.

142 ibid. 
remedy". ${ }^{143}$ Thus, the NHRC can play an essential role in protecting the violations of human rights in the business arena. If the NHRC is empowered to protect and prevent violations of human rights attached to the business, it can adequately protect those rights as an independent body. Thus, special provisions may be added in the NHRC Act that the NHRC will be authorized to take cognizance of the violations of human rights by the corporate bodies.

\subsection{Authority to Award Interim Relief}

NHRC should have powers to guarantee effective remedies, including interim measures to protect the life and safety of an individual and free medical treatment where necessary. Like the South African's Commission, the NHRC may also be given the power to award prompt compensation and to take the measure of redress and rehabilitation if it thinks appropriate by considering the circumstances of violations of human rights.

\section{Conclusion}

There is no doubt that the NHRC in Bangladesh has the potential to be a significant institution, but without the power to adjudicate and issue binding commands, they may be turned to be "glorified ciphers and promise of unreality" as rightly termed by Justice VR Krishna Iyer. ${ }^{144}$ From the present structure of the NHRC Act, it is may be said that the victory of the Commission largely depends on the true political volition of the government because the NHRC has to rely on it to accomplish most of its mandates. Therefore, to give the mandate to the NHRC within the current legal framework for the promotion and protection of human rights and human development in Bangladesh is nothing but to fight without a weapon. Learning lessons from other countries, it may not be wise to make the NHRC dependent on the will of the government alone to perform its functions at this age. To make the Commission more active and effective, it is necessary to make reasonable and adequate amendments in the existing provisions of the NHRC Act, which may make the NHRC as independent pro-people Commission and not as an agent of the government. An independent pro-people Commission is part and parcel to achieve the goals of SDGs. If the aforesaid recommendations are brought into light by amending the provisions of the NHRC Act 2009 by the Parliament, the NHRC may be turned into the long-cherished independent and impartial institution out of the control of government for the respect, promotion, protection and enforcement of human rights and human development in Bangladesh and only then the objectives as laid down in the NHRC Act may come true.

143 ibid.

144 Interview with Justice VR Krishna Iyer, 'Law and our Rights' The Daily Star (Dhaka, 1 June 1997) <http://www.hurights.or.jp/archives/focus/section2/1999/12/a-national-human-rights-commissionfor-bangladesh.html> accessed 14 March 2020. 